\title{
Remote Sensing of Urban Forests
}

\author{
Giovanni Sanesi ${ }^{1, *}$, Vincenzo Giannico ${ }^{1}\left[\right.$, Mario Elia ${ }^{1} @$ and Raffaele Lafortezza ${ }^{1,2}$ \\ 1 Department of Agricultural and Environmental Sciences, University of Bari “Aldo Moro", \\ Via Amendola 165/A, 70126 Bari, Italy; vincenzo.giannico@uniba.it (V.G.); mario.elia@uniba.it (M.E.); \\ raffaele.lafortezza@uniba.it (R.L.) \\ 2 Department of Geography, The University of Hong Kong, Pokfulam Road, Hong Kong, China \\ * Correspondence: giovanni.sanesi@uniba.it; Tel.: +39-080-5443023
}

Received: 10 October 2019; Accepted: 11 October 2019; Published: 15 October 2019

\begin{abstract}
Urban forests and green infrastructures at large are of critical importance for contemporary cities as they provide a wide range of ecosystem services (ESS) that enhance the quality of life of urban dwellers. Remote sensing technologies have greatly contributed to assessing and mapping the spatial distribution of ESS in urban areas, although more research is needed given the availability of new sensors from multiple satellites and platforms and the particular characteristics of urban environments (e.g., high heterogeneity). This Special Issue hosts papers focusing on the temporal and spatial dynamics of urban forests with special attention given to the most recent remote sensing technologies as well as advanced methods for processing geospatial data and extracting meaningful information.
\end{abstract}

Keywords: remote sensing technologies; ecosystem services; green infrastructure; LiDAR; urban forestry indicators

\section{Introduction}

Through the provision of ecosystem services (ESS), urban forests and green infrastructures provide multiple benefits for urban dwellers making cities more resilient to climate change by enhancing, for example, the degree of shading, evaporative cooling, biodiversity, rainwater interception, and storage and filtration functions [1-6]. To date, the majority of available studies have considered one or more ESS provided by specific forest areas in cities and proposed remote sensing methods to quantify the amount of services in relation to their benefits for citizens. Recent studies have attempted to assess the ESS provided by urban green spaces through the integration of social data with remotely sensed data, such as high-resolution satellite images and Laser Imaging Detection and Ranging (LiDAR) data $[7,8]$. Given the increasing availability of satellite images from different sensors, the spread of LiDAR data and growing potential of cloud-based services (i.e., Google Earth Engine or Amazon Web Services), there is a need for innovative research focusing on advanced remote sensing applications for monitoring and assessing urban forest areas and associated ESS.

This Special Issue includes research studies focusing on the temporal dynamics of urban forests $[9,10]$ and their distribution in space through the application of advanced semantic segmentation techniques [11] and in relationship with green space accessibility [12], the implementation of laser scanner for improving allometry-based forest biometrics [13], and a review investigating the state of the art of remote sensing in urban forestry [14] (see Table 1). 
Table 1. Remote sensing applications presented in this Special Issue.

\begin{tabular}{|c|c|c|c|c|c|}
\hline Source & Title & Country & Application(s) & Technique(s) & Data \\
\hline Choi et al. & $\begin{array}{l}\text { Urban Forest Growth and Gap } \\
\text { Dynamics Detected by Yearly } \\
\text { Repeated Airborne Light Detection } \\
\text { and Ranging (LiDAR): A Case } \\
\text { Study of Cheonan, South Korea }\end{array}$ & South Korea & $\begin{array}{l}\text { Assess annual changes in } \\
\text { the tridimensional structure } \\
\text { of urban forest canopies }\end{array}$ & $\begin{array}{l}\text { Point cloud height } \\
\text { distribution analysis }\end{array}$ & Airborne Laser Scanning \\
\hline Deng et al. & $\begin{array}{l}\text { A Methodology to Monitor Urban } \\
\text { Expansion and Green Space } \\
\text { Change Using a Time Series of } \\
\text { Multi-Sensor SPOT and Sentinel-2A } \\
\text { Images }\end{array}$ & China & $\begin{array}{l}\text { Monitor urban expansion } \\
\text { and green space change }\end{array}$ & $\begin{array}{l}\text { Principal Component } \\
\text { Analysis; Iterative } \\
\text { Self-Organizing Data } \\
\text { Analysis Technique and } \\
\text { Maximum Likelihood } \\
\text { classifier }\end{array}$ & $\begin{array}{l}\text { SPOT-2, 3, } 5 \text { and } \\
\text { Sentinel-2A }\end{array}$ \\
\hline Stubbings et al. & $\begin{array}{l}\text { A Hierarchical Urban Forest Index } \\
\text { Using Street-Level Imagery and } \\
\text { Deep Learning }\end{array}$ & United Kingdom & $\begin{array}{l}\text { Measure the quantity of } \\
\text { visible vegetation from } \\
\text { pedestrians' point of view } \\
\text { (Urban Street Tree } \\
\text { Vegetation Index) }\end{array}$ & $\begin{array}{l}\text { Random Forest; Pyramid } \\
\text { Scene Parsing Network and } \\
\text { a Hierarchical Multilevel } \\
\text { Model }\end{array}$ & Google Street View imagery \\
\hline Zhang et al. & $\begin{array}{l}\text { Spatial Accessibility of Urban } \\
\text { Forests in the Pearl River Delta } \\
\text { (PRD), China }\end{array}$ & China & $\begin{array}{l}\text { Measure forest accessibility } \\
\text { and explore its relationship } \\
\text { with dwellers' } \\
\text { socio-economic condition }\end{array}$ & Regression analysis & $\begin{array}{l}\text { Landsat-derived products } \\
\text { (High-Resolution Global } \\
\text { Maps of 21st-Century Forest } \\
\text { Cover Change [15]) }\end{array}$ \\
\hline Lin and Jiang & $\begin{array}{l}\text { Mensuration and Its Preliminary } \\
\text { Validation in an Urban Boreal } \\
\text { Forest: Aiming at One Cornerstone } \\
\text { of Allometry-Based Forest } \\
\text { Biometrics }\end{array}$ & Finland & $\begin{array}{l}\text { Estimate diameter at breast } \\
\text { height in a complex urban } \\
\text { forest }\end{array}$ & $\begin{array}{l}\text { Successive Cone-based } \\
\text { Fitting }\end{array}$ & Mobile Laser Scanning \\
\hline Li et al. & $\begin{array}{l}\text { Remote Sensing in Urban Forestry: } \\
\text { Recent Applications and Future } \\
\text { Directions }\end{array}$ & Multiple countries & $\begin{array}{l}\text { Review of remote sensing } \\
\text { applications in urban } \\
\text { forestry }\end{array}$ & Various & Various \\
\hline
\end{tabular}




\section{Overview of Contributions}

A wide range of disturbances driven by natural (i.e., extreme weather conditions) and human factors (i.e., high level of pollution; fires) can have dramatic effects on urban forests due to their low level of resilience [16]. Therefore, it is important to understand how disturbances may affect urban green spaces over time and space both in terms of forest cover and structure. In this regard, Choi et al. [9] derived changes in urban forest structure from a set of LiDAR point-cloud data in South Korea during the period of 2012-2015. The authors considered forest structure variables such as the distribution of growth area and damaged areas, change in vertical density profile as well as the dynamics of forest canopies (i.e., opening and closing). The authors found that conducting the analysis in a relatively small time frame is sufficient to detect anomalies in canopies and therefore the potential effects of disturbances.

In the panorama of remote sensing, LiDAR point-cloud data represent one of the best choices for describing vertical forest structure; however, multispectral satellite data are more cost-effective and consistent over time when investigating canopy cover and, more generally, land use/land cover distribution. In the study conducted by Deng et al. [10], the authors developed a method to detect land use change in the Hangzhou area (China) by integrating images acquired by Satellite Pour l'Observation de la Terre (SPOT) and Sentinel-2A satellites spanning the past 20 years. Their methods, which include multi-date Principal Component Analysis (PCA) and a hybrid classifier, resulted in higher accuracies compared to traditional land use change detection approaches. Further, the authors have demonstrated the suitability of this approach for change detection analysis especially in large cities where the high level of urbanization and land use change may determine the loss of large green spaces and urban forest vegetation.

With the increasing availability of big data (e.g., multi-source satellite images) and computational power (e.g., cloud-computing), a new range of studies can take advantage of available technologies to enhance remote sensing capabilities at the urban scale. For example, Stubbings et al. [11] developed a method based on semantic segmentation algorithms (Pyramid Scene Parsing Network) and a hierarchical multilevel model to retrieve a measure of the quantity of visible vegetation from pedestrians' point of view, namely the Urban Street Tree Vegetation Index. The method, which used more than 200,000 street-level images classified by means of Deep Convolution Neural Networks, represents a valuable addition to traditional remote sensing sources (e.g., aerial or satellite data). Additionally, the index can be used as an estimate of human green perception and therefore, for the measurement of cultural ESS, human health and well-being. Similarly, Zhang et al. [12] studied the potential of recent cloud service technologies (i.e., Google Earth Engine) to explore the relations between urban dwellers' socio-economic condition and green space accessibility in the Pearl River Delta urban forests. The authors used a set of remote sensing data (e.g., tree cover, forest cover gain and loss) in conjunction with other Geographic Information System (GIS) maps (e.g., Global Human Settlement and population distribution) to develop a Google Earth Engine framework aimed at measuring accessibility to urban forests. The travel time to reach the closest urban forest area was found to be negatively correlated with gross domestic product density.

In recent decades, the use of airborne LiDAR has exponentially increased the ability to estimate with high accuracy the biomass of large forest areas [4,17-19]. On the contrary, other technologies integrating laser scanners (e.g., mobile laser scanner, terrestrial laser scanner) have been less investigated, although they would be very useful in highly heterogeneous areas such as urban forests. Lin and Jiang [13] developed a Diameter at Breast Height (DBH) estimation algorithm based on Mobile Laser Scanning (MLS) that avoids the stem-bending effect. Their algorithm, which predicted the DBH of a complex boreal urban forest located in Finland with good accuracy $\left(R^{2}=0.81\right.$, RMSE $\left.=52.1 \mathrm{~mm}\right)$, demonstrated the suitability of MLS-based methods for forest metrics estimation in complex urban environments.

Urban forests are characterized by a high degree of diversity in terms of spatial and temporal dynamics. In the review article by Li et al. [14], the application of remote sensing in urban forestry was explored from the perspective of three distinctive themes: multi-source, multi-temporal and multi-scale 
inputs. The authors found that multi-sensor analyses, especially including multispectral and LiDAR data, gave the best results in terms of accuracy and cost-effectiveness although more research focusing on data processing efficiency and standardization among algorithms is warranted.

The study of urban forests with particular attention given to the estimation of ESS provided by these green areas presents a wide variety of data and methods. Future research should focus on the extraction of metrics that are able to describe the tridimensional structure of a forest (e.g., LiDAR or Synthetic Aperture Radar data) instead of a mere bidimensional land use classification. Additionally, there is a need for the standardization of methods with a preference for those which are accurate and of simple application aimed at creating a common language (i.e., streamlined framework) in the research community. Such characteristics would make the application of the most recent remote sensing technologies, as well as advanced data processing methods, more usable by urban planners and technicians and at the same time, make the results more accessible and transferable to stakeholders and users $[20,21]$.

Funding: This research received no external funding.

Acknowledgments: We thank all the authors that contributed to this Special Issue with their highly valuable research. We also thank the reviewers for their effort in keeping the quality of the contributions very high and the editorial team of MDPI, in particular Cris Wang, for their support throughout the production of this Special Issue.

Conflicts of Interest: The authors declare no conflict of interest.

\section{References}

1. Sanesi, G.; Gallis, C.; Kasperidus, H.D. Urban Forests and Their Ecosystem Services in Relation to Human Health. In Forests, Trees and Human Health; Nilsson, K., Sangster, M., Gallis, C., Hartig, T., de Vries, S., Seeland, K., Schipperijn, J., Eds.; Springer: Dordrecht, The Netherlands, 2011; pp. 23-40. ISBN 978-90-481-9806-1.

2. Armson, D.; Stringer, P.; Ennos, A.R. The effect of street trees and amenity grass on urban surface water runoff in Manchester, UK. Urban For. Urban Green. 2013, 12, 282-286. [CrossRef]

3. Coutts, A.M.; Tapper, N.J.; Beringer, J.; Loughnan, M.; Demuzere, M. Watering our cities: The capacity for Water Sensitive Urban Design to support urban cooling and improve human thermal comfort in the Australian context. Prog. Phys. Geogr. Earth Environ. 2013, 37, 2-28. [CrossRef]

4. Pesola, L.; Cheng, X.; Sanesi, G.; Colangelo, G.; Elia, M.; Lafortezza, R. Linking above-ground biomass and biodiversity to stand development in urban forest areas: A case study in Northern Italy. Landsc. Urban Plan. 2017, 157, 90-97. [CrossRef]

5. Escobedo, F.J; Giannico, V.; Jim, C.Y.; Sanesi, G.; Lafortezza, R. Urban forests, ecosystem services, green infrastructure and nature-based solutions: Nexus or evolving metaphors? Urban For. Urban Green. 2019, 37, 3-12. [CrossRef]

6. Van der Jagt, A.P.N.; Smith, M.; Ambrose-Oji, B.; Konijnendijk, C.C.; Giannico, V.; Haase, D.; Lafortezza, R.; Nastran, M.; Pintar, M.; Železnikar, Š.; et al. Co-creating urban green infrastructure connecting people and nature: A guiding framework and approach. J. Environ. Manag. 2019, 233, 757-767. [CrossRef] [PubMed]

7. Lafortezza, R.; Giannico, V. Combining high-resolution images and LiDAR data to model ecosystem services perception in compact urban systems. Ecol. Indic. 2019, 96, 87-98. [CrossRef]

8. Giannico, V.; Lafortezza, R.; John, R.; Sanesi, G.; Pesola, L.; Chen, J. Estimating Stand Volume and Above-Ground Biomass of Urban Forests Using LiDAR. Remote Sens. 2016, 8, 339. [CrossRef]

9. Choi, H.; Song, Y.; Jang, Y. Urban Forest Growth and Gap Dynamics Detected by Yearly Repeated Airborne Light Detection and Ranging (LiDAR): A Case Study of Cheonan, South Korea. Remote Sens. 2019, 11, 1551. [CrossRef]

10. Deng, J.; Huang, Y.; Chen, B.; Tong, C.; Liu, P.; Wang, H.; Hong, Y. A Methodology to Monitor Urban Expansion and Green Space Change Using a Time Series of Multi-Sensor SPOT and Sentinel-2A Images. Remote Sens. 2019, 11, 1230. [CrossRef]

11. Stubbings, P.; Peskett, J.; Rowe, F.; Arribas-Bel, D. A Hierarchical Urban Forest Index Using Street-Level Imagery and Deep Learning. Remote Sens. 2019, 11, 1395. [CrossRef] 
12. Zhang, R.; Chen, J.; Park, H.; Zhou, X.; Yang, X.; Fan, P.; Shao, C.; Ouyang, Z. Spatial Accessibility of Urban Forests in the Pearl River Delta (PRD), China. Remote Sens. 2019, 11, 667. [CrossRef]

13. Lin, Y.; Jiang, M. A New Algorithm for MLS-Based DBH Mensuration and Its Preliminary Validation in an Urban Boreal Forest: Aiming at One Cornerstone of Allometry-Based Forest Biometrics. Remote Sens. 2018, 10, 749. [CrossRef]

14. Li, X.; Chen, W.Y.; Sanesi, G.; Lafortezza, R. Remote Sensing in Urban Forestry: Recent Applications and Future Directions. Remote Sens. 2019, 11, 1144. [CrossRef]

15. Hansen, M.C.; Potapov, P.V.; Moore, R.; Hancher, M.; Turubanova, S.A.; Tyukavina, A.; Thau, D.; Stehman, S.V.; Goetz, S.J.; Loveland, T.R.; et al. High-Resolution Global Maps of 21st-Century Forest Cover Change. Science 2013, 342, 850-853. [CrossRef] [PubMed]

16. Elia, M.; Giannico, V.; Lafortezza, R.; Sanesi, G. Modeling fire ignition patterns in Mediterranean urban interfaces. Stoch. Environ. Res. Risk Assess. 2019, 33, 169-181. [CrossRef]

17. Means, J.E.; Acker, S.A.; Fitt, B.J.; Renslow, M.; Emerson, L.; Hendrix, C.J. Predicting forest stand characteristics with airborne scanning LiDAR. Photogramm. Eng. Remote Sens. 2000, 66, 1367-1371.

18. Næsset, E. Predicting forest stand characteristics with airborne scanning laser using a practical two-stage procedure and field data. Remote Sens. Environ. 2002, 80, 88-99. [CrossRef]

19. Zhao, K.; Suarez, J.C.; Garcia, M.; Hu, T.; Wang, C.; Londo, A. Utility of multitemporal lidar for forest and carbon monitoring: Tree growth, biomass dynamics, and carbon flux. Remote Sens. Environ. 2018, 204, 883-897. [CrossRef]

20. Ugolini, F.; Massetti, L.; Sanesi, G.; Pearlmutter, D. Knowledge transfer between stakeholders in the field of urban forestry and green infrastructure: Results of a European survey. Land Use Policy 2015, 49, 365-381. [CrossRef]

21. Ugolini, F.; Sanesi, G.; Steidle, A.; Pearlmutter, D. Speaking “Green”: A Worldwide Survey on Collaboration among Stakeholders in Urban Park Design and Management. Forests 2018, 9, 458. [CrossRef]

(C) 2019 by the authors. Licensee MDPI, Basel, Switzerland. This article is an open access article distributed under the terms and conditions of the Creative Commons Attribution (CC BY) license (http://creativecommons.org/licenses/by/4.0/). 